\title{
Methicillin resistant Staphylococcus aureus: a review of the present Indian scenario and drug treatment
}

\author{
Anant Parasher*, Pushpender Khatana
}

Department of Medicine, Guru Teg Bahadur Hospital, New Delhi, India

Received: 03 March 2020

Accepted: 27 March 2020

*Correspondence:

Dr. Anant Parasher,

E-mail: anant02jan@gmail.com

Copyright: ( ) the author(s), publisher and licensee Medip Academy. This is an open-access article distributed under the terms of the Creative Commons Attribution Non-Commercial License, which permits unrestricted non-commercial use, distribution, and reproduction in any medium, provided the original work is properly cited.

\begin{abstract}
Methicillin-resistant strains of $S$. aureus cause infections that are associated with higher mortality rates and increased length of hospital stays, than infections caused by methicillin-susceptible strains. The mechanism by which MRSA strains develop resistance is by the production of an altered penicillin-binding protein (PBP), which has a decreased affinity for most semisynthetic penicillins. MRSA has increased in prevalence and has become endemic in the Indian subcontinent, with incidence varying from $25 \%$ in Western regions to $50 \%$ in Southern India. A multi-centric study conducted across 15 tertiary care centers in India from 2008 to 2009 showed overall prevalence of MRSA infection to be $41 \%$ among $S$. aureus isolates, and recent Indian studies from 2014 and 2018 have also suggested an increasing prevalence of MRSA. Transmission is mainly horizontal and concerns high risk populations (patients with prolonged hospital stay, on haemodialysis, receiving cancer treatment or specific medications that affect immune function, intravenous drug users and individuals who have had surgery in the recent past. Community Acquired MRSA has emerged as significant pathogen responsible for potentially fatal infections including life-threatening pneumonia, necrotizing fasciitis, endocarditis, osteomyelitis, severe sepsis, and toxic shock syndrome. Diagnosis is mainly by gram stain, culture and quantitative PCR. Newer techniques include Multi-locus sequence typing (MLST), Pulsedfield gel electrophoresis (PFGE), Bacteriophage typing, spa locus typing and SCCmec typing. Although Vancomycin was previously considered the definitive treatment for serious MRSA infections, the emergence of less-susceptible strains, poor clinical outcomes, and increased nephrotoxicity with high-dose therapy have deterred its use as first-line therapy in many cases. Although a number of new and effective antimicrobial agents are now available for the treatment of MRSA, their exact role and choice of agent needs to be well-defined.
\end{abstract}

Keywords: Altered penicillin-binding protein, Endocarditis, Linezolid, Methicillin-resistant S. aureus, Toxic shock syndrome

\section{INTRODUCTION}

Staphylococcus aureus is a gram-positive and coagulasepositive spherical bacterium of approximately $1 \mu \mathrm{m}$ in diameter, which forms grape-like clusters. It is a body commensal, which is often present asymptomatically on skin and mucous membranes of nose and gut of healthy individuals. ${ }^{1}$ Nearly $20 \%$ of individuals are persistent nasal carriers of $S$. aureus, $30 \%$ are intermittent carriers, and $50 \%$ cases are non-carriers. ${ }^{2}$ Most affected cases are infected by these indigenously carried commensal $S$. aureus strains. ${ }^{3}$

Recently, S. aureus has shown a high level of resistance against multiple antibiotic classes. This resistance first emerged in 1942, within two years of the introduction of penicillin. ${ }^{4}$ Methicillin, a semisynthetic antibiotic was developed in the late 1950s, and in 1960, the first case of 
methicillin-resistant $S$. aureus (MRSA) was clinically identified..$^{5}$ Although these "archaic" MRSA strains were first found in the United Kingdom and parts of Europe, new cases started to emerge after 1980, slowing spreading and transforming into a global catastrophe.

Methicillin-resistant strains of $S$. aureus cause infections that are associated with higher mortality rates and increased length of hospital stays, as compared to infections caused by methicillin-susceptible strains. ${ }^{6-8}$ The mechanism by which MRSA strains develop resistance is by the production of an altered penicillinbinding protein (PBP), which has a decreased affinity for most semisynthetic penicillins. The protein is encoded by an acquired gene, mec $\mathrm{A}$, which is carried on a mobile genetic element (MGE) designated as staphylococcal cassette chromosome mec (SCCmec). ${ }^{9-11}$ The insertion of these mobile genetic elements into the chromosomes of susceptible strains causes the emergence of methicillin resistance. These strains are a major concern due to their high morbidity and mortality, as they are responsible for almost 25 to $50 \%$ of $S$. aureus infections in the hospital setting. ${ }^{12}$

\section{REVIEW OF LITERATURE}

\section{Prevalence, risk factors and sub-types}

In a recent European survey, the most common organisms in Skin and Soft Tissue Infections (SSTIs) were $S$. aureus ( $71 \%$ cases) with $22.5 \%$ being MRSA. MRSA prevalence varied widely among these European countries as well. ${ }^{13}$ In a US study spanning over 10 years ${ }^{14}$, incidence of $S$. aureus increased overall, with an increase in community onset MRSA infections. Presently, Methicillin-resistant Staphylococcus aureus (MRSA) is one of the most commonly implicated agents in nosocomial infections in the US intensive care units, and is one of the leading causes of surgical site infections in North American tertiary care hospitals. ${ }^{15,16}$

MRSA has increased in prevalence and has become endemic in the Indian subcontinent, with incidence varying from $25 \%$ in Western regions to $50 \%$ in Southern India. ${ }^{17,18} \mathrm{~A}$ multi-centric study conducted across 15 tertiary care centers in India from 2008 to 2009 showed overall prevalence of MRSA infection to be $41 \%$ among S. aureus isolates. ${ }^{19}$ The prevalence of MRSA in a study from Chennai ${ }^{18}$ was reported as $40-50$ per cent, and a high prevalence of MRSA (35\% in ward and $43 \%$ in ICU) was observed from blood culture specimens in a study from Delhi as well. ${ }^{20}$ Patel et al reported a change in the blood stream infections with $S$. aureus emerging as the predominant pathogen in recent years, with MRSA strains becoming increasingly common among them. ${ }^{17}$

The prevalence of MRSA varies between regions, and between hospitals in the same region as seen in a study from Delhi ${ }^{21}$ where the MRSA prevalence in nosocomial infections varied from 7.5 to 41.3 per cent between three tertiary care hospitals. Community acquired-MRSA (CA MRSA) isolates are now being increasingly reported from India, which are mainly isolated from skin and soft tissue infections. D' Souza et al studied 412 confirmed cases of MRSA and found that 54 per cent were true CAMRSA possessing the SCCmec IV and SCC mec V genes. Chatterjee et al found the overall prevalence of $S$. aureus nasal colonization was 52.3 per cent and that of MRSA was 3.89 per cent in the community. ${ }^{22,23}$

In a 2014 study in Central India, out of 192 coagulase positive strains, a total of $112(58.33 \%)$ strains showed resistance to methicillin, and of the remaining 93 coagulase negative strains, 12 (12.9\%) showed methicillin resistance. ${ }^{24}$ In a 2018 study done by Singh et al in 300 school-going children of age 5-15 years from North India, nasal carriage of $S$. aureus was found in 140 $(46.67 \%)$ children, whereas MRSA colonization was found in $23(7.67 \%)$ children. ${ }^{25}$ The male children were found to have a slightly higher nasal colonization with both $S$. aureus and MRSA, as compared to the female children.

In recent years, Methicillin-resistant Staphylococcus aureus (MRSA) strains have emerged as a cause of nosocomial infections responsible for rapidly progressive, potential fatal diseases. ${ }^{26}$ Independent risk factors for MRSA include old age, extended hospital stay, immunesuppression, hemodialysis, inadequate antimicrobial therapy, peripheral hypo-perfusion, diabetes and multiple indwelling devices. ${ }^{27}$

New genetically distinct reservoirs of MRSA strains, including Healthcare-associated/Hospital acquired methicillin-resistant $S$. aureus (HA-MRSA), Communityacquired MRSA (CA-MRSA) and livestock-acquired MRSA (LA-MRSA) have now been described. ${ }^{28}$ Rapid evolution of new genetic lineages/clonal complexes (CC) and resistance to multiple classes of antibiotics, has worsened the MRSA led health crisis. ${ }^{29,30}$

\section{Transmission}

Transmission of methicillin resistance to Staphylococcus aureus is mainly horizontal in hospital and community settings, and presents a significant clinical challenge to the management of MRSA led infections. CA- MRSA strains occur in people who have not been recently hospitalized/low risk populations such as children, prisoners, athletes, soldiers and adults presenting to the emergency department with a positive contact/travel history. HA-MRSA strains first appeared, and are prevalent in high risk populations such as patients with prolonged hospital/ICU stay, undergoing haemodialysis, receiving cancer treatment or specific medications that affect immune function, intravenous drug users and individuals who have had surgery in the recent past. ${ }^{31}$

MRSA infections present a highly variable course, and may progress substantially within one to two days of 
initial symptom onset; rapidly taking hold in human tissues and eventually become resistant to treatment. ${ }^{32,33}$ Transmission occurs through crowding and close contact, open wounds and via clothing such as cotton towels and wash cloths, privacy drapes and curtains, splash aprons, scrub suits and lab coats. ${ }^{34}$ The $5 \mathrm{Cs}$ are used to remember transmission of MRSA: Crowding, Contact (skin-to-skin), Compromised skin (open wounds), Contaminated (items and surfaces) and lack of Cleanliness. $^{31}$

\section{Clinical manifestations and disease spectrum}

CA MRSA and HA MRSA have emerged as significant pathogens responsible for potentially fatal infections which have been tabulated below. ${ }^{32,34}$ These infections are seen to be more prevalent in high risk groups.

\section{Common clinical presentations ${ }^{32,34}$}

- Acute bacterial skin and skin structure infections such as folliculitis, furuncles (boils), carbuncles, styes, abscesses, impetigo, paronychia, wound infections and cellulitis.

- Osteomyelitis

- Endocarditis

- Pneumonia and Urinary tract infections/ Cystitis

- Meningitis

- Infections in Pacemaker Pockets/ Implants

- Acute food poisoning due to toxins

- Toxic shock syndrome and staphylococcal scalded skin syndrome.

TSST-1 or other enterotoxin producing strains cause the Staphylococcal toxic shock syndrome, in which the patient presents with a constellation of fever, hypoperfusion and shock, a red rash and multi-organ failure. Risks include tampon use, nasal packing and surgical wounds. Ingestion of preformed Staphylococcal enterotoxin causes an acute, self-limited gastroenteritis with an incubation period of 2-6 hours. ${ }^{35}$

Infection may occur without an apparent focus or entry site, and the patient should be evaluated for endocarditis, mycotic aneurysms or vertebral infection. Skin/soft tissues infections include folliculitis, cellulitis, furuncles, carbuncles, abscesses, impetigo (may occur in combination with Streptococcus pyogenes), Breast mastitis, abscesses of the spleen, kidney, epidural space; visceral or deep abscesses occuring almost always due to hematogenous seeding from bacteremia. ${ }^{36,37}$

Nearly $6-25 \%$ of patients present with endocarditis due to $S$. aureus bacteremia, affecting both the native and prosthetic valves. ${ }^{38,39}$ Bone involvement is evidenced by osteomyelitis (most commonly vertebral osteomyelitis secondary to bacteremia/discitis and epidural abscess), and infections in the prosthetic joints/implants. ${ }^{32,34}$
CA-MRSA strains are also responsible for Nosocomial necrotizing pneumonia, and for right-sided endocarditis via septic pulmonary emboli. ${ }^{40,41}$ The release of TSST1 toxin is mainly responsible for toxin associated gastroenteritis and the subsequent toxic shock syndrome. CNS manifestations may present as post-operative or bacteremia associated meningitis. ${ }^{42}$

\section{Diagnosis and rapid identification techniques}

An appropriate specimen is obtained depending upon the type and site of infection, and analyzed either by using biochemical or enzyme-based tests. A Gram stain would show typical gram-positive cocci in clusters, and a culture on mannitol salt agar (selective medium with 7$9 \% \mathrm{NaCl}$ ) produces yellow-colored colonies as a result of mannitol fermentation and a decrease in the $\mathrm{pH}$. For differentiation on the species level, the tests done are Catalase (positive for all Staphylococcus species), Coagulase (positive for S. aureus), DNAse, Lipase and Phosphatase tests. Phage typing can be performed in cases of staphylococcal food poisoning to determine the source of infection. ${ }^{43}$

Rapid and reliable techniques have now been developed due to recent genetic advances, which support infection control strategies to limit bacterial spread and ensure the appropriate use of antibiotics.

Outbreaks of MRSA infection are being increasingly identified by quantitative PCR. ${ }^{43,44}$ "Band-based" or "sequence-based" methods are now employed to observe the evolution pattern and adaptability of Staphylococcus aureus to existing and new antibiotics. ${ }^{45}$

Multi-locus sequence typing (MLST), Pulsed-field gel electrophoresis (PFGE), Bacteriophage typing, Spa locus typing and SCC mec typing are also used to determine the origin of MRSA strains. ${ }^{46}$

\section{Drugs and management strategies}

The Principle Characteristics of Current US Food and Drug Administration-Approved Anti-infective Agents for MRSA have been given in Table $1 . .^{41,47,48}$

- Vancomycin remains the mainstay of treatment for the management of MRSA ever since 1958. No drug to date has shown superiority to vancomycin in the treatment of MRSA infections with the possible exception of Linezolid in hospital-acquired pneumonia (HAP). Vancomycin has been recommended in consensus guidelines to predict successful therapy, and continuous infusion has been associated with lower rates of nephrotoxicity. ${ }^{48,49,50}$

- Teicoplanin is a glycopeptide with a similar mode of action as vancomycin. Recent data has concluded that teicoplanin (at higher and appropriate dosing) is not inferior to vancomycin and may be associated with a lower rate of adverse events. ${ }^{32,48}$ 
Table 1: Principle characteristics of US-FDA approved drugs against MRSA..$^{41,47,48}$

\begin{tabular}{|c|c|c|c|c|c|c|}
\hline Agent & $\begin{array}{l}\text { Bacterial } \\
\text { effect } \\
\text { and } \\
\text { mechanism } \\
\text { of action } \\
\end{array}$ & $\begin{array}{l}\text { Route of } \\
\text { administration and } \\
\text { dosing } \\
\text { recommendations }\end{array}$ & $\begin{array}{l}\text { Dosage } \\
\text { adjustment } \\
\text { for renal and } \\
\text { hepatic } \\
\text { impairment }\end{array}$ & Adverse events & Advantages & Disadvantages \\
\hline Vancomycin & $\begin{array}{l}\text { "Slow" } \\
\text { Bactericidal } \\
\text { activity } \\
\text { (concentration } \\
\text { independent); } \\
\text { cell wall } \\
\text { inhibition }\end{array}$ & $\begin{array}{l}\text { IV: } 500 \mathrm{mg} \text { q6h or } \\
1000 \mathrm{mg} \text { q } 12 \mathrm{~h} \text {; } \\
\text { high-dose therapy } \\
\text { ( } 15 \text { to } 20 \mathrm{mg} / \mathrm{kg} \\
\text { total body weight q } 8 \\
\text { to } 12 \mathrm{~h} \text { ) } \\
\text { currently } \\
\text { recommended } \\
\text { when } \mathrm{MIC} \text { values } \\
\text { are } 1 \mu \mathrm{g} / \mathrm{mL}\end{array}$ & $\begin{array}{l}\text { Renal: Dosing } \\
\text { adjustments are } \\
\text { necessary } \\
\text { Hepatic: no } \\
\text { adjustment needed }\end{array}$ & $\begin{array}{l}\text { Nephrotoxicity, red } \\
\text { man syndrome }\end{array}$ & $\begin{array}{l}\text { Inexpensive; } \\
>50 \text { years of } \\
\text { clinical } \\
\text { experience }\end{array}$ & $\begin{array}{l}\text { Resistance - } \\
\text { development of } \\
\text { VRSA; increasing } \\
\text { MIC } \\
\text { values associated } \\
\text { with poor } \\
\text { outcomes; } \\
\text { nephrotoxicity } \\
\text { with higher doses }\end{array}$ \\
\hline Linezolid & $\begin{array}{l}\text { Bacteriostatic; } \\
\text { Protein } \\
\text { synthesis } \\
\text { inhibition (23S } \\
\text { RNA at } 50 \mathrm{~S} \\
\text { ribosomal } \\
\text { subunit) }\end{array}$ & $\begin{array}{l}\text { IV or PO: } 600 \mathrm{mg} \\
\text { q12h }\end{array}$ & $\begin{array}{l}\text { Renal: None } \\
\text { Hepatic: No } \\
\text { specific } \\
\text { recommendations }\end{array}$ & $\begin{array}{l}\text { Thrombocytopenia } \\
\text { and anemia; } \\
\text { peripheral and } \\
\text { optic neuropathy; } \\
\text { lactic acidosis; } \\
\text { serotonin } \\
\text { syndrome }\end{array}$ & $\begin{array}{l}100 \% \\
\text { bioavailable } \\
\text { oral } \\
\text { formulation; } \\
\text { good lung } \\
\text { penetration; } \\
\text { active against } \\
\text { Vancomycin } \\
\text { Resistant } \\
\text { Enterococci }\end{array}$ & $\begin{array}{l}\text { Bacteriostatic; } \\
\text { serious adverse } \\
\text { events with } \\
\text { longterm } \\
\text { use }(>14 \mathrm{~d}) ; \\
\text { increasing } \\
\text { linezolid- } \\
\text { resistance; high } \\
\text { drug cost }\end{array}$ \\
\hline Daptomycin & $\begin{array}{l}\text { Bactericidal } \\
\text { (concentration } \\
\text { dependent); } \\
\text { membrane } \\
\text { depolarization } \\
\text { (Ca++ } \\
\text { dependent) }\end{array}$ & $\begin{array}{l}\text { IV: S. aureus } \\
\text { bacteremia: } 6 \mathrm{mg} / \mathrm{kg} \\
\text { (total body } \\
\text { weight) q24h; } \\
\text { some experts } \\
\text { recommend higher } \\
\text { doses }(8 \text { to } 10 \mathrm{mg} / \\
\mathrm{kg} \text { ) for bacteremia/ } \\
\text { infective } \\
\text { endocarditis } \\
\text { indications }\end{array}$ & $\begin{array}{l}\text { Renal: For } \\
\text { Creatinine } \\
\text { Clearance }<30 \\
\mathrm{~mL} / \mathrm{min}, \mathrm{q} 48 \mathrm{~h} \\
\text { Hepatic: No } \\
\text { specific } \\
\text { recommendations }\end{array}$ & $\begin{array}{l}\text { CPK elevation; } \\
\text { myopathy; } \\
\text { peripheral } \\
\text { neuropathy; } \\
\text { reports of } \\
\text { rhabdomyolysis } \\
\text { and eosinophilic } \\
\text { pneumonia }\end{array}$ & $\begin{array}{l}\text { Rapidly } \\
\text { bactericidal; } \\
\text { effective for } \\
\text { MRSA } \\
\text { bloodstream } \\
\text { infections } \\
\text { and } \\
\text { right-side } \\
\text { endocarditis; } \\
\text { active against } \\
\text { VRE }\end{array}$ & $\begin{array}{l}\text { Inactivated by } \\
\text { pulmonary } \\
\text { surfactant and } \\
\text { should not be } \\
\text { used to treat } \\
\text { pneumonia;; } \\
\text { suboptimal clinical } \\
\text { outcomes in } \\
\text { patients with } \\
\text { reduced renal } \\
\text { function; high } \\
\text { drug cost }\end{array}$ \\
\hline Tigecycline & $\begin{array}{l}\text { Bacteriostatic; } \\
\text { Protein } \\
\text { synthesis } \\
\text { inhibition (at } \\
\text { 30S ribosomal } \\
\text { subunit) }\end{array}$ & $\begin{array}{l}\text { IV: loading dose of } \\
100 \mathrm{mg} \text { followed } \\
\text { by } 50 \mathrm{mg} \mathrm{q} 12 \mathrm{~h}\end{array}$ & $\begin{array}{l}\text { Renal: None } \\
\text { Hepatic: Child- } \\
\text { Pugh } \\
\text { class C, } 100 \mathrm{mg} \\
\text { single dose, } \\
\text { maintenance } 25 \mathrm{mg} \\
\text { q12h }\end{array}$ & $\begin{array}{l}\text { GI side effects } \\
\text { (nausea and } \\
\text { vomiting are } \\
\text { common) }\end{array}$ & $\begin{array}{l}\text { Active } \\
\text { against } \\
\text { VRE }\end{array}$ & $\begin{array}{l}\text { Bacteriostatic; high } \\
\text { rates of GI } \\
\text { adverse events; } \\
\text { higher risk of } \\
\text { mortality than } \\
\text { comparator } \\
\text { agents; high drug } \\
\text { cost }\end{array}$ \\
\hline Telavancin & $\begin{array}{l}\text { Bactericidal } \\
\text { (concentration } \\
\text { dependent); } \\
\text { cell } \\
\text { wall inhibition } \\
\text { and membrane } \\
\text { depolarization }\end{array}$ & $\begin{array}{l}\mathrm{IV}: 10 \mathrm{mg} / \mathrm{kg} \text { (total } \\
\text { body weight) q24h }\end{array}$ & $\begin{array}{l}\text { Renal: } \mathrm{CrCl} 30-50 \\
\mathrm{~mL} / \mathrm{min}, 7.5 \mathrm{mg} / \mathrm{kg} \\
\mathrm{q} 12 \mathrm{~h} ; \mathrm{CrCl} 10 \text { to } \\
<30,10 \mathrm{mg} / \mathrm{kg} \\
\mathrm{q} 48 \mathrm{~h} ; \mathrm{CrCl}<10, \\
\text { limited data } \\
\text { Hepatic: No } \\
\text { specific } \\
\text { recommendations }\end{array}$ & $\begin{array}{l}\text { GI side effects } \\
\text { (including } \\
\text { dysgeusia); mild } \\
\text { QT prolongation; } \\
\text { Nephrotoxicity }\end{array}$ & $\begin{array}{l}\text { Rapidly } \\
\text { bactericidal } \\
\text { against } \\
\text { MRSA, } \\
\text { VISA, and } \\
\text { VRSA; } \\
\text { active against } \\
\text { MRSA } \\
\text { strains } \\
\text { resistant to } \\
\text { vancomycin, } \\
\text { linezolid, and } \\
\text { daptomycin }\end{array}$ & $\begin{array}{l}\text { Nephrotoxicity; } \\
\text { lower clinical } \\
\text { outcomes in } \\
\text { patients with } \\
\text { reduced renal } \\
\text { function; Avoided } \\
\text { during pregnancy }\end{array}$ \\
\hline Ceftaroline & $\begin{array}{l}\text { Bactericidal } \\
\text { (time } \\
\text { dependent); } \\
\text { cell } \\
\text { wall inhibition }\end{array}$ & IV: $600 \mathrm{mg} \mathrm{q} 12 \mathrm{~h}$ & $\begin{array}{l}\text { Renal: } \mathrm{CrCl} 31-50 \\
\mathrm{~mL} / \mathrm{min}, 400 \mathrm{mg} \\
\text { q12h; } \mathrm{CrCl} 15-30, \\
300 \mathrm{mg} \mathrm{q} 12 \mathrm{~h} ; \mathrm{CrCl} \\
<15,200 \mathrm{mg} \mathrm{q} 12 \mathrm{~h} \\
\text { Hepatic: No } \\
\text { specific } \\
\text { recommendations }\end{array}$ & $\begin{array}{l}\text { Well tolerated }(<5 \% \\
\text { incidence of } \\
\text { diarrhea, nausea, } \\
\text { rash) }\end{array}$ & $\begin{array}{l}\text { Bactericidal; } \\
\text { well } \\
\text { tolerated; } \\
\text { moderately } \\
\text { expensive }\end{array}$ & $\begin{array}{l}\text { Limited reports on } \\
\text { treatment of } \\
\text { MRSA infections }\end{array}$ \\
\hline
\end{tabular}


Table 2: Recommendations for the treatment of methicillin-resistant Staphylococcus aureus (MRSA) ${ }^{31,33,41}$

\begin{tabular}{|c|c|c|}
\hline Manifestation & Treatment & Adult dose \\
\hline \multicolumn{3}{|l|}{ Skin and soft-tissue infection (SSTI) } \\
\hline Abscess, furuncles, Carbuncles & Incision and drainage & \\
\hline \multirow{5}{*}{$\begin{array}{l}\text { Purulent cellulitis (defined as cellulitis } \\
\text { associated with purulent drainage or } \\
\text { exudate in the absence of a drainable } \\
\text { abscess) }\end{array}$} & Clindamycin & $300-450 \mathrm{mg}$ PO TID \\
\hline & TMP-SMX & 1-2 DS tab PO BID \\
\hline & Doxycycline & $100 \mathrm{mg}$ PO BID \\
\hline & Minocycline & $200 \mathrm{mg} 31$, then $100 \mathrm{mg}$ PO BID \\
\hline & Linezolid & $600 \mathrm{mg}$ PO BID \\
\hline \multirow{4}{*}{$\begin{array}{l}\text { Nonpurulent cellulitis } \\
\text { (defined as cellulitis with } \\
\text { no purulent drainage } \\
\text { or exudate and no } \\
\text { associated abscess) }\end{array}$} & $\begin{array}{l}\text { beta-lactams (eg, cephalexin } \\
\text { and dicloxacillin) }\end{array}$ & 500 mg PO QID \\
\hline & Clindamycin & $300-450$ mg PO TID \\
\hline & $\begin{array}{l}\text { b-lactam (eg, amoxicillin) and/or } \\
\text { TMP-SMX or a tetracycline }\end{array}$ & $\begin{array}{l}\text { Amoxicillin: } 500 \text { PO mg TID. See above } \\
\text { for TMP-SMX and tetracycline dosing }\end{array}$ \\
\hline & Linezolid & $600 \mathrm{mg}$ PO BID \\
\hline \multirow{5}{*}{ Complicated SSTI } & Vancomycin & $15-20 \mathrm{mg} / \mathrm{kg} /$ dose IV every8-12 h \\
\hline & Linezolid & $600 \mathrm{mg}$ PO/IV BID \\
\hline & Daptomycin & 4 mg/kg/dose IV QD \\
\hline & Telavancin & $10 \mathrm{mg} / \mathrm{kg} / \mathrm{dose}$ IV QD \\
\hline & Clindamycin & 600 mg PO/IV TID \\
\hline \multicolumn{3}{|l|}{ Bacteremia and infective endocarditis } \\
\hline \multirow[t]{2}{*}{ Bacteremia } & Vancomycin & $15-20 \mathrm{mg} / \mathrm{kg} / \mathrm{dose}$ IV every $8-12 \mathrm{~h}$ \\
\hline & Daptomycin & $6 \mathrm{mg} / \mathrm{kg} /$ dose IV QD \\
\hline Infective endocarditis, native valve & Vancomycin and Daptomycin & \\
\hline $\begin{array}{l}\text { Infective endocarditis, prosthetic valve } \\
\text { bacteremia }\end{array}$ & $\begin{array}{l}\text { Vancomycin and } \\
\text { gentamicin and Rifampin }\end{array}$ & $\begin{array}{l}15-20 \mathrm{mg} / \mathrm{kg} / \text { dose IV every } 8-12 \mathrm{~h} \\
1 \mathrm{mg} / \mathrm{kg} / \text { dose IV every } 8 \mathrm{~h} \\
300 \mathrm{mg} \text { PO/IV every } 8 \mathrm{~h}\end{array}$ \\
\hline \multirow{3}{*}{ Persistent bacteremia } & Vancomycin & $15-20 \mathrm{mg} / \mathrm{kg} / \mathrm{dose}$ IV every $8-12 \mathrm{~h}$ \\
\hline & Linezolid & 600 mg PO/IV BID \\
\hline & Clindamycin & 600 mg PO/IV TID \\
\hline \multirow{5}{*}{$\begin{array}{l}\text { Bone and joint infections Osteomyelitis } \\
\text { Septic arthritis }\end{array}$} & Vancomycin & $15-20 \mathrm{mg} / \mathrm{kg} / \mathrm{dose}$ IV every $8-12 \mathrm{~h}$ \\
\hline & Daptomycin & 6 mg/kg/day IV QD \\
\hline & Linezolid & $600 \mathrm{mg} \mathrm{PO/IV} \mathrm{BID}$ \\
\hline & Clindamycin & $600 \mathrm{mg}$ PO/IV TID \\
\hline & TMP-SMX and Rifampin & $\begin{array}{l}3.5-4.0 \mathrm{mg} / \mathrm{kg} / \mathrm{dose} \mathrm{PO} / \mathrm{IV} \\
\text { every } 8-12 \mathrm{~h}\end{array}$ \\
\hline \multirow{5}{*}{$\begin{array}{l}\text { Septic arthritis } \\
\text { Prosthetic joint, spinal } \\
\text { implant infections }\end{array}$} & Vancomycin & $15-20 \mathrm{mg} / \mathrm{kg} / \mathrm{dose}$ IV every8-12 h \\
\hline & Daptomycin & $6 \mathrm{mg} / \mathrm{kg} /$ day IV QD \\
\hline & Linezolid & 600 mg PO/IV BID \\
\hline & Clindamycin & $600 \mathrm{mg}$ PO/IV TID \\
\hline & TMP-SMX & $3.5-4.0 \mathrm{mg} / \mathrm{kg} / \mathrm{dose}$ PO/IV every $8-12 \mathrm{~h}$ \\
\hline \multicolumn{3}{|l|}{ Central nervous system infections } \\
\hline \multirow{3}{*}{$\begin{array}{l}\text { Meningitis Brain abscess, subdural } \\
\text { empyema, spinal epidural abscess }\end{array}$} & Vancomycin & $15-20 \mathrm{mg} / \mathrm{kg} / \mathrm{dose}$ IV every $8-12 \mathrm{~h}$ \\
\hline & Linezolid & $600 \mathrm{mg}$ PO/IV BID \\
\hline & TMP-SMX & $5 \mathrm{mg} / \mathrm{kg} /$ dose PO/IV every $8-12 \mathrm{~h}$ \\
\hline \multirow{3}{*}{$\begin{array}{l}\text { Brain abscess, subdural } \\
\text { empyema, spinal epidural abscess } \\
\text { Septic thrombosis of cavernous or dural } \\
\text { venous sinus }\end{array}$} & Vancomycin & $15-20 \mathrm{mg} / \mathrm{kg} / \mathrm{dose}$ IV every $8-12 \mathrm{~h}$ \\
\hline & Linezolid & 600 mg PO/IV BID \\
\hline & TMP-SMX & $5 \mathrm{mg} / \mathrm{kg} /$ dose PO/IV every $8-12 \mathrm{~h}$ \\
\hline
\end{tabular}

- Lipoglycopeptides such as Oritavancin, Telavancin, and Dalbavancin are semi-synthetic lipopolypeptide analogues of vancomycin with activity against MRSA. In common with vancomycin, they also act by inhibition of cell wall synthesis. ${ }^{48,49}$
- Anti-MRSA Cephalosporins namely Ceftaroline and ceftobiprole have in-vitro activity against MRSA due to their affinity for the penicillin-binding protein PBP2a, and offer great promise in the treatment of MRSA. ${ }^{41,48}$ 
- Daptomycin belongs to a new cyclic lipopeptide class of antibiotics and has a unique mechanism of action, with calcium-dependent binding to the cytoplasmic membrane resulting in rapid membrane depolarization and efflux of potassium. This results in the arrest of DNA, RNA, and protein synthesis and leads to rapid cell death. Although effective, daptomycin is inactivated by pulmonary surfactant and cannot be used in the treatment of pneumonia. ${ }^{34,49,50}$

- Linezolid is an oxazolidinone class antibiotic that inhibits bacterial protein synthesis by preventing the formation of the 70S initiation complex with activity against MRSA. Unlike, vancomycin, linezolid achieves high levels in the epithelial lining fluid of the lungs, making it a promising candidate for treatment of patients with MRSA associated HAP. ${ }^{48,49,50}$ Tedizolid is a new oxazolidinone that has been specifically engineered to improve bioavailability and efficacy, and reduce the toxicity as compared with linezolid. It is dosed once daily and its potency is 4 to 16 times greater than linezolid. ${ }^{48-50}$

- Quinupristin/Dalfopristin (QD) is a combination of two semi-synthetic streptogramin antibiotics which acts by binding to the 50S bacterial ribosome in two sequential steps, and thus inhibits bacterial protein synthesis. Each drug alone is bacteriostatic against susceptible gram-positive organisms including MRSA, but the combination is synergistic and bactericidal. ${ }^{32,48}$

- Tigecycline is a parenteral glycylcycline antibiotic, with in vitro activity against many gram-positive bacteria, including MRSA. The main treatmentlimiting adverse effect of tigecycline is nausea and vomiting, which occurs in 30 to $40 \%$ of treated patients. ${ }^{48-50}$

Many of these agents with activity against drug-resistant gram-positive pathogens are being developed primarily for treatment of MRSA infections, including tedizolid, dalbavancin, and oritavancin. ${ }^{51}$ The current recommendations for treatment of MRSA have been summarized in Table 2.

\section{Prevention and screening}

Patient screening with nasal cultures upon hospital admission prevents the co-habitation of MRSA carriers with non-carriers.

Alcohol has been proven to be an effective surface sanitizer against MRSA, and can be used in conjunction with quaternary ammonium to extend the longevity of the sanitizing action. Some important prevention measures as recommended by the $\mathrm{CDC}$ have been mentioned below. ${ }^{31}$

- Hand washing, alcohol-based and chlorhexidine based handrubs remain somewhat effective.
- $\quad$ Prevention for health care workers by wearing gloves when examining or treating body areas with a suspected cutaneous lesion; and proper hand washing following examination or treatment is required, including proper hand hygiene; gloving; wearing eye, mouth, and nose protection; gowning; cleaning equipment with disinfectant; and the appropriate cleaning of laundry.

- The CDC recommends that surfaces and floors be cleaned with disinfectants approved by the Environmental Protection Agency using List-H on the Environmental Protection Agency's list.

\section{Resistance trends and need for newer drugs}

Better treatment of this evolving organism requires a better understanding of it by both the researchers and the treating clinicians. Vancomycin remains a viable option, but there still remains uncertainty about the best dosing strategy. Lipoglycopeptides as a class, all the agents show in vitro potency greater than Vancomycin. ${ }^{48-50}$ However, their long half-life and complex pharmacokinetics may preclude the use of these agents in critically ill patients. Anti-MRSA cephalosporins (Ceftobiprole and Ceftaroline) show greater promise in the treatment of MRSA. ${ }^{32,48}$

Daptomycin is currently the only antibiotic to have shown non-inferiority to Vancomycin in the treatment of MRSA bacteremia. ${ }^{48,49}$

Vancomycin resistance has become evident in select clinical settings through rising MICs, growing awareness of hetero-resistance and emergence of intermediateresistant and fully resistant strains. ${ }^{49}$ Although the resistance to linezolid and daptomycin remains low, some cases have shown development of resistance through point mutations and horizontal transmission of cfrmediated resistance to linezolid. ${ }^{49,50}$ These points highlight the ongoing need for new and more potent antimicrobial therapies for MRSA.

\section{DISCUSSION}

Methicillin-resistant Staphylococcus aureus (MRSA) continues to be associated with significant morbidity and mortality. Although Vancomycin was previously considered the definitive treatment for serious MRSA infections, the emergence of less-susceptible strains, poor clinical outcomes, and increased nephrotoxicity with high-dose therapy have deterred its use as first-line therapy in many cases. ${ }^{49,50}$ Few drugs till date have shown superiority to Vancomycin in the treatment of MRSA with possible exception of Linezolid in HAP. ${ }^{48}$ Although a number of new and effective antimicrobial agents are now available for the treatment of MRSA, their exact role and choice of agent needs to be welldefined.

\section{Funding: No funding sources}


Conflict of interest: None declared

Ethical approval: Not Required

\section{REFERENCES}

1. Gould D, Chamberlaine A. Staphylococcus aureus: a review of the literature. J Clin Nurs 1995;4:5-12.

2. Wertheim HF, Melles DC, Vos MC, van Leeuwen W, van Belkum A, Verbrugh HA, Nouwen JL. The role of nasal carriage in Staphylococcus aureus infections. Lancet Infect Dis 2005;5:751-62.

3. Williams RE, Jevons MP, Shooter RA, Hunter CJ, Girling JA, Griffiths JD, Taylor GW. Nasal staphylococci and sepsis in hospital patients. $\mathrm{Br}$ Med J 1959;2:658-62.

4. Kirby WM. Extraction of a highly potent penicillin inactivator from penicillin resistant staphylococci. Science 1944;99:452-3.

5. Jevons MP. "Celbenin"-resistant staphylococci. $\mathrm{Br}$ Med J. 1961;1:124-5.

6. Wolk DM, Struelens MJ, Pancholi P, Davis T, Della-Latta P, Fuller D, et al. Rapid detection of Staphylococcus aureus and methicillin-resistant $\mathrm{S}$. aureus (MRSA) in wound specimens and blood cultures: multicenter preclinical evaluation of the Cepheid Xpert MRSA/SA skin and soft tissue and blood culture assays. J Clin Microbiol. 2009;47:8236.

7. Fortuin-de Smidt MC, Singh-Moodley A, Badat R, Quan V, Kularatne R, Nana T, et al. for GERMSSA. Staphylococcus aureus bacteraemia in Gauteng academic hospitals, South Africa. Int J Infect Dis. 2015;30:41-8.

8. Thampi N, Showler A, Burry L, Bai AD, Steinberg M, Ricciuto DR, et al. Multicenter study of health care cost of patients admitted to hospital with Staphylococcus aureus bacteremia: impact of length of stay and intensity of care. Am J Infect Control 2015;43:739-44.

9. Utsui Y, Yokota T. Role of an altered penicillinbinding protein in methicillin- and cephem-resistant Staphylococcus aureus. Antimicrob Agents Chemother. 1985;28:397-403.

10. Matsuhashi M, Song MD, Ishino F, Wachi M, Doi $\mathrm{M}$, Inoue $\mathrm{M}$, et al. Molecular cloning of the gene of a penicillin-binding protein supposed to cause high resistance to beta-lactam antibiotics in Staphylococcus aureus. J Bacteriol. 1986;167:97580.

11. Katayama Y, Ito T, Hiramatsu K. A new class of genetic element, staphylococcus cassette chromosome mec, encodes methicillin resistance in Staphylococcus aureus. Antimicrob Agents Chemother. 2000;44:1549-55.

12. Diekema DJ, Pfaller MA, Schmitz FJ, Smayevsky J, Bell J, Jones RN, et al. Survey of infections due to Staphylococcus species: frequency of occurrence and antimicrobial susceptibility of isolates collected in the United States, Canada, Latin America, Europe, and the Western Pacific region for the
SENTRY Antimicrobial Surveillance Program, 1997-1999. Clin Infect Dis. 2001;32(2):S114-32.

13. Sader HS, Farrell DJ, Jones RN. Antimicrobial susceptibility of Gram-positive cocci isolated from skin and skin-structure infections in European medical centres. Int $\mathrm{J}$ Antimicrob Agents. 2010;36:28-32.

14. Tracy LA, Furuno JP, Harris AD, Singer M, Langenberg P, Roghmann MC. Staphylococcus aureus infections in US veterans, Maryland, USA, 1999-2008. Emerg Infect Dis. 2011;17:441-8.

15. Hidron AI, Edwards JR, Patel J, Horan TC, Sievert DM, Pollock DA, et al. National Healthcare Safety Network Team; Participating National Healthcare Safety Network Facilities. NHSN annual update: antimicrobial-resistant pathogens associated with healthcare-associated infections: annual summary of data reported to the National Healthcare Safety Network at the Centers for Disease Control and Prevention, 2006-2007. Infect Control Hosp Epidemiol. 2008;29(11):996-1011.

16. Dukic VM, Lauderdale DS, Wilder J, Daum RS, David MZ. Epidemics of community-associated methicillin-resistant Staphylococcus aureus in the United States: a meta-analysis. PLoS One. 2013;8(1):e52722.

17. Patel AK, Patel KK, Patel KR, Shah S, Dileep P. Time trends in the epidemiology of microbial infections at a tertiary care center in west India over last 5 years. J Assoc Physicians India. 2010;58(Suppl):37-40.

18. Gopalakrishnan R, Sureshkumar D. Changing trends in antimicrobial susceptibility and hospital acquired infections over an 8 year period in a tertiary care hospital in relation to introduction of an infection control programme. J Assoc Physicians India. 2010;58(Suppl):25-31.

19. Joshi S, Ray P, Manchanda V, Bajaj J, Chitnis D, Gautam V, et al. Methicillin resistant Staphylococcus aureus (MRSA) in India: prevalence \& susceptibility pattern. Indian $\mathrm{J}$ Med Res. 2013;137(2):363.

20. Wattal C, Goel N, Oberoi JK, Raveendran R, Datta S, Prasad KJ. Surveillance of multidrug resistant organisms in tertiary care hospital in Delhi, India. J Assoc Physicians India. 2010;58(Suppl):32-6.

21. Gadepalli R, Dhawan B, Kapil A, Sreenivas V, Jais $\mathrm{M}$, Gaind R, et al. Clinical and molecular characteristics of nosocomial methicillin-resistant Staphylococcus aureus skin and soft tissue isolates from three Indian hospitals. J Hosp Infect. 2009;73:253-63.

22. D'Souza N, Rodrigues C, Mehta A. Molecular characterization of Methicillin-resistant Staphylococcus aureus with emergence of epidemic clones of sequence type (ST)22 and ST 772 in Mumbai, India. J Clin Microbiol. 2010;48:1806-11.

23. Chatterjee SS, Ray P, Aggarwal A, Das A, Sharma M. A community based study on nasal carriage of 
Staphylococcus aureus. Indian J Med Res. 2009;130:742-8.

24. Mantri R, Karyakarte A, Ambhore N, Kombade S. Prevalence of Methicillin Resistant Staphylococcus aureus in tertiary care hospital, Central India. Int J Curr Microbiol App Sci. 2014;3(10):582-6.

25. Singh AK, Agarwal L, Kumar A, Sengupta C, Singh RP. Prevalence of nasal colonization of methicillinresistant Staphylococcus aureus among schoolchildren of Barabanki district, Uttar Pradesh, India. J Family Med Prim Care 2018;7:162-6.

26. Monecke S, Coombs G, Shore AC, Coleman DC, Akpaka P, Borg M, et al. A field guide to pandemic, epidemic and sporadic clones of methicillinresistant Staphylococcus aureus. PloS one. 2011;6(4).

27. Naves K, Trindade N, Filho P. Methicillin-resistant Staphylococcus aureus bloodstream infection: risk factors and clinical outcome in non-intensive-care units. Revista da Sociedade Brasileira de Medicina Tropical. 2012;45(2):189-93.

28. Grema HA, Geidam YA, Gadzama GB, Ameh JA, Suleiman A. Methicillin resistant Staphylococcus aureus (MRSA): a review. Adv Anim Vet Sci. 2015;3(2):79-98.

29. Köck R, Becker K, Cookson B, van Gemert-Pijnen JE, Harbarth S, Kluytmans JA, et al. Methicillinresistant Staphylococcus aureus (MRSA): burden of disease and control challenges in Europe. Euro Surveillance. 2010;15(41).

30. Cooper BS, Medley GF, Stone SP, Kibbler CC, Cookson BD. Methicillin resistant Staphylococcus aureus in hospitals and the community: stealth dynamics and control catastrophes. Proc Natl Acad Sci. 2004;101(27):10223-8.

31. The National Institute for Occupational Safety and Health (NIOSH). Centers for Disease Control and Prevention (CDC). MRSA and the Workplace. Page last reviewed: August 17, 2015. Available at: https://www.cdc.gov/niosh/topics/mrsa/default.html. Accessed 15 January 2020.

32. Mayo Clinic. MRSA Infection: Symptoms and Causes. Page last reviewed: Oct. 18, 2018. Available at: https://www.mayoclinic.org/diseasesconditions/mrsa/symptoms-causes/syc-20375336. Accessed 18 January 2020.

33. Lambert M. IDSA Guidelines on the Treatment of MRSA Infections in Adults and Children. Am Fam Physician. 2011 Aug 15;84(4):455-63.

34. Nichols H. MRSA: Causes, Symptoms, Prevention and Treatments. Medical News Today. 2015. Available at: http://www.medicalnewstoday.com/articles/10634.p hp.

35. Pallin DJ, Binder WD, Allen MB, Lederman M, Parmar S, Filbin MR et al. Clinical trial: comparative effectiveness of cephalexin plus trimethoprim-sulfamethoxazole versus cephalexin alone for treatment of uncomplicated cellulitis: a randomized controlled trial. Clin Infect Dis 2013;56:1754.

36. Lee BK, Crossley K, Gerding DN. The association between Staphylococcus aureus bacteremia and bacteriuria. Am J Med 1978;65:303.

37. Thwaites GE, Edgeworth JD, Gkrania-Klotsas E, Kirby A, Tilley R, Török ME et al. Clinical management of Staphylococcus aureus bacteraemia. Lancet Infect Dis 2011;11:208.

38. Cosgrove SE, Vigliani GA, Campion M, Fowler VG, Abrutyn E, Corey GR, et al. Initial low dose gentamicin for Staphylococcus aureus bacteremia and endocarditis is nephrotoxic. Clin Infect Dis 2009;48:713.

39. Heldman AW, Hartert TV, Ray SC, Daoud EG, Kowalski TE, Pompili VJ et al. Oral antibiotic treatment of right sided staphylococcal endocarditis in injection drug users: prospective randomized comparison with parenteral therapy. Am J Med 1996;101:68.

40. Wunderink RG, Niederman MS, Kollef MH, Shorr AF, Kunkel MJ, Baruch A et al. Linezolid in methicillin resistant Staphylococcus aureus nosocomial pneumonia: a randomized, controlled study. Clin Infect Dis 2012;54:621.

41. Liu C, Bayer A, Cosgrove S, Daum R, Fridkin S, Gorwitz R et al. Clinical Practice Guidelines by the Infectious Diseases Society of America for the Treatment of Methicillin-Resistant Staphylococcus Aureus Infections in Adults and Children. IDSA Guidelines. Clin Infect Dis Advance Access. 2011.

42. Beckham JD, Tyler KL. Neuro-Intensive Care of Patients with Acute CNS Infections. Neurotherapeutics. 2012;9:124-38.

43. Francois P, Schrenzel J. Rapid Diagnosis and Typing of Staphylococcus aureus . Staphylococcus: Molecular Genetics. Caister Academic Press. 2008.

44. Mackay IM. Real-Time PCR in Microbiology: From Diagnosis to Characterization. Caister Academic Press. 2007.

45. Deurenberg RH, Stobberingh EE. The evolution of Staphylococcus aureus. Infect Genet Evol. 2008;8(6):747-63.

46. Kim J. Understanding the Evolution of MethicillinResistant Staphylococcus aureus. Clin Microbiol Newsl. 2009;31(3):17-23.

47. Rodvold KA, McConeghy KW. MethicillinResistant Staphylococcus aureus Therapy: Past, Present, and Future. Clin Infect Dis. 2014;58(S1):S20-7.

48. Craig WA. Basic pharmacodynamics of antibacterials with clinical applications to the use of beta-lactams, glycopeptides, and linezolid. Infect Dis Clin North Am. 2003;17(3):479-501.

49. Holmes NE, Tong SY, David JS, Van Hal SJ. Treatment of methicillin-resistant Staphylococcus aureus: vancomycin and beyond. Semin Respir Crit Care Med. 2015;36(1):17-30. 
50. Choo EJ, Chambers HF. Treatment of MethicillinResistant Staphylococcus aureus Bacteremia. Infect Chemother. 2016;48(4):267-73.

51. Klevens RM, Morrison MA, Nadle J et al. Invasive methicillin resistant Staphylococcus aureus infections in the United States. JAMA 2007;298:1763-71.
Cite this article as: Parasher A, Khatana P.

Methicillin resistant Staphylococcus aureus: a review of the present Indian scenario and drug treatment. Int J Adv Med 2020;7:860-8. 